\title{
Nutritional diarrhoea in the milk-fed lamb and its relation to the intake of sugar
}

\author{
By D. M. WALKER AND G. J. FAICHNEY \\ Department of Animal Husbandry, University of Sydney, Australia \\ (Received 20 Fune 1963-Accepted 3 December 1963)
}

Nutritional diarrhoea in young animals is of common occurrence when they are fed on experimental diets and is attributable to a wide variety of causes, amongst which are: fat-free diets (Lambert, Jacobson, Allen \& Zaletel, 1953; Cunningham \& Loosli, I954), diets containing highly unsaturated vegetable fat (Gullickson, Fountaine \& Fitch, I942; Wiese, Johnson, Mitchell \& Nevens, I947; Adams, Gander, Gullickson \& Sautter, 1959; Adams, Gullickson, Gander \& Sautter, 1959), high intakes of lactose or minerals (Fischer \& Sutton, 1949; Owen, Jacobson, Allen \& Homeyer, 1958), abnormal dietary sodium:calcium ratios (Kastelic, Bentley \& Phillips, 1950), unhomogenized fat in the diet (Bate, Espe \& Cannon, 1946), and formation of hard curd in the abomasum due to overfeeding (Sheehy, 1955). A high dietary level of sugar, apart from the toxic effects of lactose as such, is known to cause diarrhoea in calves (Rojas, Schweigert \& Rupel, 1948; Blaxter \& Wood, 1953).

The experiments reported in this paper relate the intake of sugar in experimental diets to the incidence of diarrhoea in lambs during the milk-feeding period.

\section{EXPERIMENTAL AND RESULTS}

Details of the lambs, their diets, housing and management are reported elsewhere (Walker \& Faichney, $1964 a, b$ ). Nutritional diarrhoea in these experiments is defined in terms of the dry-matter content of the faeces. However, such comparisons only apply within a particular species, since there is considerable variation between species in the normal dry-matter content of the faeces. Blaxter \& Wood (I953) have classified faeces in terms of 'normal', 'loose' and 'diarrhoeal' with respective dry-matter percentages of $19.7,13.2$ and 9.2 . Normal faeces of lambs have a higher percentage of dry matter than those of calves, the mean value being about $30 \%$ (cf. Blaxter $\&$ Wood, 1953; Netke, Gardner \& Kendall, 1962). This difference in the dry-matter percentage of the faeces also occurs with adults of these species, values of $17 \%$ for cows and $32 \%$ for sheep having been reported (Dukes, 1955).

In our experiments scouring lambs showed considerable variation in the dry-matter percentage of their faeces, though any values lower than $15 \%$ were classified as 'diarrhoeal'.

The sugar content of the diets was expressed in terms of hexose equivalent ; lactose values were converted into the equivalent weight of monosaccharide and expressed as hexose sugar. 
In the first experiment four diets were given to each of twenty-four lambs in a latin square design. In the second experiment six lambs were given diets in which the intake of sugar was controlled, and in the third experiment six lambs were given a nitrogen-free diet. All diets were given at a similar level of energy intake.

Expt I. The four diets given in this experiment were based upon dried whole cow's milk, with additions of glucose or casein to three of them. Table i gives details of the diets. Table 2 shows the intakes of hexose equivalent $/ \mathrm{kg}$ live weight $24 \mathrm{~h}$ for the lambs on each of the four diets, together with the dry-matter percentage of the faeces.

Table I. Composition of the diets (values expressed per $100 \mathrm{~g}$ dry matter)

Crude protein (g)
Ether extractives (g)
Ash (g)
N-free extractives (by
$\quad$ difference) (g)
Lactose (g)
Hexose equivalent (by
$\quad$ calculation) (g)
Dried whole milk (g)
Glucose (g)
Butter oil (g)
Casein (g)
Glyceryl monostearate (g)
Minerals $\dagger$ (g)
Energy (kcal)
Protein calories as per-
centage of total calories
Energy intake (kcal/kg
live weight 24 h)

\begin{tabular}{|c|c|c|c|c|c|}
\hline \multicolumn{4}{|c|}{ Expt I } & \multirow{2}{*}{$\begin{array}{c}\text { Expt } 2 \\
\text { Diet } \\
\text { no. I A }\end{array}$} & \multirow{2}{*}{$\begin{array}{c}\text { Expt } 3 \\
\text { N-free } \\
\text { diet }\end{array}$} \\
\hline $\begin{array}{l}\text { Diet } \\
\text { no. I }\end{array}$ & $\begin{array}{c}\text { Diet } \\
\text { no. } 2\end{array}$ & $\begin{array}{c}\text { Diet } \\
\text { no. } 3\end{array}$ & $\begin{array}{l}\text { Diet } \\
\text { no. } 4\end{array}$ & & \\
\hline 17.6 & $23 \cdot 1$ & 28.5 & $32 \cdot 8$ & $22 \cdot 5$ & -- \\
\hline $17 \cdot 1$ & $22 \cdot 3$ & $27 \cdot 6$ & $25 \cdot 8$ & 38.8 & $46 \cdot 2$ \\
\hline $3 \cdot 7$ & $4 \cdot 8$ & 5.9 & 57 & 4.8 & $6 \cdot 6$ \\
\hline $6 r \cdot 6$ & 49.8 & $38 \cdot 0$ & 357 & 33.9 & $47^{\circ} 2$ \\
\hline $22 \cdot 6$ & $29 \cdot 6$ & $36 \cdot 6$ & $34 \cdot 2$ & $29 \cdot 8$ & - \\
\hline $62 \cdot 0$ & $50 \cdot 1$ & $38 \cdot 5$ & $36 \cdot 0$ & $33 \cdot 2$ & $47 \cdot 2$ \\
\hline 61.8 & $8 I \cdot 0$ & 100.0 & $93 \cdot 6$ & 83.5 & - \\
\hline $3^{8 \cdot 2}$ & 19.0 & -- & - & $I \cdot 9$ & $47 \cdot 2$ \\
\hline- & - & $\ldots$ & -- & 16.6 & $4 I \cdot 0$ \\
\hline- & 一 & -- & 6.4 & - & - \\
\hline$\cdots$ & $\longrightarrow$ & - & - & - & $5 \cdot 1$ \\
\hline- & 一 & -- & 一. & - & 6.7 \\
\hline 483 & 521 & 556 & $55^{6}$ & 610 & 600 \\
\hline $20 \cdot 2$ & $24 \cdot 8$ & $28 \cdot 7$ & 33.0 & $20 \cdot 6$ & - \\
\hline 107 & II3 & 122 & 120 & 109 & I 10 \\
\hline
\end{tabular}

Table 2. Mean values, with their standard errors, for the intake by the lambs of hexose equivalent and of ether extractives and for the dry-matter content $(\%)$ of their faeces

\begin{tabular}{|c|c|c|c|c|c|c|c|}
\hline \multirow[b]{2}{*}{$\begin{array}{c}\text { Expt } \\
\text { no. }\end{array}$} & \multirow[b]{2}{*}{ Diet } & \multirow[b]{2}{*}{$\begin{array}{l}\text { No. of } \\
\text { lambs }\end{array}$} & \multirow{2}{*}{$\begin{array}{l}\text { Hexose } \\
\text { equivalent } \\
\text { (g/kg live } \\
\text { weight } 24 \mathrm{~h} \text { ) }\end{array}$} & \multirow{2}{*}{$\begin{array}{l}\text { Ether } \\
\text { extractives } \\
\text { (g/kg live } \\
\text { weight } 24 \mathrm{~h} \text { ) }\end{array}$} & \multicolumn{2}{|c|}{$\begin{array}{c}\text { Dry-matter content of } \\
\text { faeces }\end{array}$} & \multirow{2}{*}{$\begin{array}{l}\text { No. of lambs } \\
\text { with faecal } \\
\text { dry-matter } \\
\text { content below } \\
\text { I } 5 \%\end{array}$} \\
\hline & & & & & $\%$ & Range $(\%)$ & \\
\hline I & I & $24 *$ & I $3.6 \pm 0.4$ & $3.8 \pm 0.1$ & $16 \cdot 2 \pm 2.8$ & $5 \cdot 9-4 x \cdot 7$ & 17 \\
\hline I & 2 & 24 & $10.8 \pm 0.2$ & $4.8 \pm 0.1$ & $23.1 \pm 2.5$ & $6 \cdot 5-50 \cdot 7$ & 8 \\
\hline I & 3 & 24 & $8.4 \pm 0.2$ & $6.0 \pm 0.1$ & $35 \cdot 2 \pm 1 \cdot 6$ & $23 \cdot 2-50 \cdot 5$ & 0 \\
\hline $\mathbf{I}$ & 4 & 24 & $7 \cdot 8 \pm 0.2$ & $5.6 \pm 0.1$ & $36 \cdot 7 \pm 2 \cdot 1$ & $19.5-66 \cdot 7$ & 0 \\
\hline 2 & I A & 6 & $6.0 \pm 0.1$ & $7.0 \pm 0.1$ & $42 \cdot 3 \pm 2 \cdot 0$ & $34 \cdot 6-47 \cdot 6$ & 0 \\
\hline 3 & N-free & 6 & $8.8 \pm 0.2$ & $8.6 \pm 0.2$ & $27.7 \pm 3.8$ & $16 \cdot 6-4 I \cdot 8$ & 0 \\
\hline
\end{tabular}

- Values for the faecal dry-matter content do not include those for eight lambs given diet no. I and one lamb given diet no. 2 which had profuse diarrhoea, preventing the separate collection of urine and faeces. 
When the intake of hexose equivalent was above about $10 \mathrm{~g} / \mathrm{kg}$ live weight $24 \mathrm{~h}$ the dry-matter percentage of the faeces decreased and scouring was of common occurrence. However, not all animals were affected and three of the twenty-four produced normal faeces with all the diets. No separation of faeces and urine was attempted with eight lambs given diet no. I and one lamb given diet no. 2 , which had profuse diarrhoea. The results of this experiment are given in Table 2.

Expt 2. It was apparent from the results of Expt I that when the intake of hexose equivalent $/ \mathrm{kg}$ live weight was above about $10 \mathrm{~g} / 24 \mathrm{~h}$ the majority of lambs developed diarrhoea. In Expt 2 a diet ( $\mathrm{A}$ ) was prepared that had the same content of protein energy, as a percentage of total energy, as diet no. I, Expt I. The intake of sugar was controlled so that the lambs received a maximum of about $6 \mathrm{~g}$ hexose equivalent $/ \mathrm{kg}$ live weight $24 \mathrm{~h}$. Details of the diet are shown in Table 1. The energy concentration was increased by adding butter oil, which was homogenized with the other constituents of the diet. When this modified diet was given at the same daily energy intake as that in Expt I no diarrhoea occurred. The results of this experiment are given in Table 2.

Expt 3. Experiments in which $\mathrm{N}$-free diets are given in the form of a synthetic milk are frequently associated with the onset of diarrhoea (Blaxter \& Wood, 195I; Cunningham \& Brisson, I 957a). Since in these $\mathrm{N}$-free diets the $\mathrm{N}$-containing portion of the diet has usually been replaced by soluble carbohydrate, rather than by fat, there is always the possibility that the occurrence of diarrhoea is caused by the relatively high levels of sugar which are offered rather than by the absence of $\mathrm{N}$ per se. In Expt 3 a $\mathrm{N}$-free diet was prepared with an upper level of hexose equivalent of about $9 \mathrm{~g} / \mathrm{kg}$ live weight $24 \mathrm{~h}$, the diet providing about $\mathrm{I}$ ro kcal total energy $/ \mathrm{kg}$ live weight $24 \mathrm{~h}$. The composition of this diet and its preparation have been given elsewhere (Walker $\&$ Faichney, $1964 a$ ). The results of the experiment are given in Table 2 ; for none of the lambs was the faecal dry-matter content below $15 \%$.

\section{DISCUSSION}

The association between high sugar intakes by young animals and the onset of diarrhoea has frequently been expressed in terms of a given percentage of sugar in the diet (Fischer \& Sutton, 1949) or a total intake of sugar (Blaxter \& Wood, 1953). The experiments reported in this paper suggest that for the lamb the intake of sugar in the milk-feeding period, expressed in terms of hexose equivalent $/ \mathrm{kg}$ live weight $24 \mathrm{~h}$, must be kept below a certain level if nutritional diarrhoea is to be prevented. That this diarrhoea was not due to a high intake of lactose is evident from the results of Expt I (Table I) in which the lactose intake was lower in those diets that caused diarrhoea (nos. I and 2) than in the other two diets.

It is now established that young animals differ at birth in their content of digestive enzymes necessary for the hydrolysis of certain disaccharides and of more complex carbohydrates. If excess amounts of certain sugars are added to the diet given early in life they cause diarrhoea, owing to their escape from digestion and absorption in the small intestine. In the young calf and lamb in the preruminant stage of development, disaccharides other than lactose cannot be digested in any quantity in the small 
intestine, owing to the low concentration or absence of digestive enzymes (Dollar \& Porter, 1957; Walker, 1959), and the presence of these disaccharides in the diet causes diarrhoea. However, in our experiments no sugars other than lactose and glucose were present in the diets.

In Expt I glucose was added to dried whole cow's milk to alter the protein concentration of the diets. The addition of glucose not only increased the total intake of hexose equivalent by the lambs, but also decreased their intake of fat. Table 2 shows the mean intakes of fat with each diet. The intake of fat was positively correlated with the faecal dry-matter content $\left(r=+0.454 ; \mathrm{df}=9^{\mathrm{I}} ; P<0.00 \mathrm{I}\right)$ within the range of $18-33 \%$ dietary protein on a dry-matter basis. However, lambs given the $\mathrm{N}$-free diet excreted faeces with a lower dry-matter content than would be predicted from the regression equation below, which relates the intake of fat to the faecal dry-matter content for all diets (ninety-three lambs), with the exception of the $\mathrm{N}$-free diet.

$$
D M=2 \cdot 54+5 \cdot 19 F,
$$

where $F=$ fat intake $(\mathrm{g} / \mathrm{kg}$ live weight $24 \mathrm{~h})$ and $D M=$ faecal dry-matter content $(\%)$.

Whereas fat-free diets may be expected to cause diarrhoea (Cunningham \& Loosli, 1954), it seems unlikely that the lowest level of fat given in our experiments could be responsible for the lowered faecal dry-matter values. Gullickson et al. (1942) gave calves skim milk containing as little as $0.01-0.02 \%$ fat without causing diarrhoea. It is possible that the high intake of fat from the $\mathrm{N}$-free diet could have caused the observed decrease in the faecal dry-matter content, relative to the other diets, as could the absence of $\mathrm{N}$ per se. However, the negative correlation between the intake of hexose

Table 3. Apparent digestibility coefficients with the standard errors of the means for diets that differed in their content of hexose equivalent

\begin{tabular}{|c|c|c|c|}
\hline \multirow[b]{2}{*}{ Constituent } & \multicolumn{2}{|c|}{ Apparent digestibility $(\%)$} & \multirow{2}{*}{$\begin{array}{c}\text { Significance } \\
\text { of difference } \\
\text { between means }\end{array}$} \\
\hline & Expt $I$, diet no. I & Expt 2, diet no. I A & \\
\hline Dry matter & $94.98 \pm 0.6 I$ & $96.79 \pm 0.62$ & NS \\
\hline Energy & $92 \cdot 90 \pm 0.93$ & $97.80 \pm 0.51$ & * \\
\hline Crude protein & $90.12 \pm 0.92$ & $95.58 \pm 0.87$ & $\because$ \\
\hline Ether extract & $97.02 \pm 0.36$ & $98.23 \pm 0.50$ & NS \\
\hline $\mathrm{N}$-free extractives (by & $96 \cdot 49 \pm 0.66$ & $98 \cdot 17 \pm 0.35$ & NS \\
\hline & $\begin{array}{l}\text { NS, not significant. } \\
* P<0.05 ;\end{array}$ & 0.0 & \\
\hline
\end{tabular}

equivalent and the faecal dry-matter content $(r=-0.594 ; \mathrm{df}=97 ; P<0.00 \mathrm{I})$ was applicable to all the diets given in our experiments, including the $\mathrm{N}$-free diet. The regression equation relating the intake of hexose equivalent to the faecal dry-matter content (ninety-nine lambs) was

$$
D M=60 \cdot 30-3 \cdot 26 H,
$$

where $H=$ hexose equivalent intake ( $\mathrm{g} / \mathrm{kg}$ live weight $24 \mathrm{~h}$ ) and $D M=$ faecal drymatter content $(\%)$.

It is known that diarrhoea can result in a lowered digestibility of the nutrients in the diet (Blaxter \& Wood, I95I). The effect of diarrhoea on the digestibility of diet no. I 
is shown by comparing the two diets ( $\mathrm{I}$ and $\mathrm{I} A$ ) in Expts I and 2 (Table 3 ), from which it is seen that a reduction in sugar intake led to the excretion of normal faeces. A further difference in the effect of these diets on the composition of the faeces is shown in Table 4 which gives values for the relative excretions of water and dry matter.

'Table 4. Mean values with their standard errors for the excretion of water and dry matter by lambs given diets that contained different amounts of hexose equivalent

\section{Component}

Faeces excreted (g/100 kcal ingested)

Water excreted (g/roo kcal ingested)

Dry matter excreted (g/100 kcal ingested)

Water excreted (g/100 $\mathrm{ml}$ ' milk' ingested)
Expt I, diet no. I

II. $6 \pm 2 \cdot 4$ $10 \cdot 6 \pm 2 \cdot 3$

$1 \cdot 0 \pm 0 \cdot 1$

$76 \pm 16$
Expt 2, diet no. I A

$$
\begin{gathered}
1.3 \pm 0.3 \\
0.8 \pm 0.2 \\
0.5 \pm 0.1 \\
7 \pm 2
\end{gathered}
$$

\begin{tabular}{|c|c|c|c|}
\hline Reference & Animal & $\begin{array}{l}\text { Hexose } \\
\text { equivalent } \\
\text { ( } \mathrm{g} / \mathrm{kg} \\
\text { live weight } \\
24 \mathrm{~h} \text { ) }\end{array}$ & $\begin{array}{c}\text { Faecal } \\
\text { consistency }\end{array}$ \\
\hline $\begin{array}{l}\text { Luecke, Culik, Thorp, } \\
\text { Blakeslee \& Nelson (1950) }\end{array}$ & Lamb & II 9 & Normal \\
\hline $\begin{array}{l}\text { Rojas et al. (1948) } \\
\text { Flipse, Huffman, Webster \& } \\
\quad \text { Duncan (1950) } \\
\text { Blaxter \& Wood (1951) } \\
\text { Cunningham \& Brisson } \\
\text { (1957a) }\end{array}$ & Calf & $\left\{\begin{array}{r}4 \cdot 8 \\
10 \cdot 5 \\
8 \cdot 2 \\
13 \cdot 6 \\
17 \cdot 0 \\
10 \cdot 0 \\
6 \cdot 0 \\
10 \cdot 8\end{array}\right.$ & $\begin{array}{l}\text { Normal } \\
\text { Diarrhoea } \\
\text { Soft } \\
\text { Normal } \\
\text { Diarrhoea } \\
\text { Diarrhoea } \\
\quad \text { at times } \\
\text { Normal } \\
\text { Diarrhoea }\end{array}$ \\
\hline $\begin{array}{l}\text { Becker, Ulirey \& Terrill (1954) } \\
\text { Cunningham \& Brisson (1957b) }\end{array}$ & Baby pig & $\left\{\begin{array}{l}54 \cdot 7 \\
27 \cdot 0 \\
47 \cdot 2\end{array}\right.$ & $\begin{array}{l}\text { Normal } \\
\text { Normal } \\
\text { Normal }\end{array}$ \\
\hline $\begin{array}{l}\text { Rechcigl, Berger, Loosli \& } \\
\text { Williams (1962) }\end{array}$ & Rat & II I I & Normal \\
\hline $\begin{array}{l}\text { Carew, Renner \& Hill (1 959) } \\
\text { Mehring, Johnson, Nesbitt \& } \\
\text { Titus (1962) }\end{array}$ & Chicken & $\left\{\begin{array}{l}53 \cdot 6 \\
29 \cdot 2 \\
54 \cdot 8\end{array}\right.$ & $\begin{array}{l}\text { Normal } \\
\text { Normal } \\
\text { Wet in } \\
\text { appearance }\end{array}$ \\
\hline $\begin{array}{l}\text { Fomon (1960) } \\
\text { Porter \& Dunn (191 5) } \\
\text { Barenberg \& Abramson (1930) }\end{array}$ & Child & $\left\{\begin{array}{l}12 \cdot 0 \\
9-40 * \\
15-17 *\end{array}\right.$ & $\begin{array}{l}\text { Normal } \\
\text { Normal } \\
\text { Heavier than } \\
\text { normal, but } \\
\text { no diarrhoea }\end{array}$ \\
\hline
\end{tabular}

Table 5. Effect of mixtures of various mono- and di-saccharides in the diet of the young of different species on the consistency of their faeces

Comparisons made with other animals during their early life show that young ruminants appear to have a lower tolerance for sugar in the diet than have many other species. The amount of information for certain species is limited because of the difficulty of finding reports of experiments that give not only the quantity of sugar 
consumed, rather than the percentage in the diet, but also the live weight of the animal and some comments on the consistency or moisture content of the faeces. Table 5 gives the sugar tolerance of some different species. There appears to be little doubt that the young of certain species, such as the pig and the chicken, are able to digest and absorb considerably larger amounts of hexose equivalent per unit of live weight than young ruminants in the preruminant stage of development. The reason for this difference is not known. The cause of the diarrhoea would appear to be an excess of monosaccharides that cannot be absorbed in the small intestine. Lindquist \& Meeuwisse ( 1962 ) have reported the occurrence of diarrhoea in an infant who was unable to absorb glucose and galactose satisfactorily, but they were unable to explain the failure.

\section{SUMMARY}

I. In three separate experiments lambs were given liquid diets which supplied different amounts of sugar. 'Total sugar in the diets was expressed as hexose equivalent.

2. Observations were made on the moisture content of the faeces; those faeces that contained more than $85 \%$ moisture were classified as 'diarrhoeal'.

3. 'Two diets that supplied the same amount of protein energy, but different amounts of energy as hexose equivalent, were compared. Six lambs given diets that supplied less than $10 \mathrm{~g}$ hexose equivalent $/ \mathrm{kg}$ live weight $24 \mathrm{~h}$ showed no diarrhoea, whereas seventeen out of twenty-four lambs given the equivalent diet, with $13.6 \mathrm{~g}$ hexose equivalent/ $\mathrm{kg}$ live weight $24 \mathrm{~h}$, showed diarrhoea.

4. Six lambs were given a nitrogen-free diet which supplied $9 \mathrm{~g}$ hexose equivalent/ $\mathrm{kg}$ live weight $24 \mathrm{~h}$. No diarrhoea was observed.

\section{REFERENCES}

Adams, R. S., Gander, J. E., Gullickson, T. W. \& Sautter, J. H. (1959). Y. Dairy Sci. 42, 562. Adams, R. S., Gullickson, T. W., Gander, J. E. \& Sautter, J. H. (1959). F. Dairy Sci. 42, 1552. Barenberg, L. H. \& Abramson, H. (r 930). Arch. Pediat. 47, I.

Bate, W., Espe, D. \& Cannon, C. Y. (1946). Y. Dairy Sci. 29, 41.

Becker, D. E., Ullrey, D. E. \& Terrill, S. W. (1954). Arch. Biochem. Biophys. 48, 178.

Blaxter, K. L. \& Wood, W. A. (195I). Brit. F. Nutr. 5, I1.

Blaxter, K. L. \& Wood, W. A. (1953). Vet. Rec. 65, 889.

Carew, L. B. Jr., Renner, R. \& Hill, F. W. (1959). Poult. Sci. 38, 1183.

Cunningham, H. M. \& Brisson, G. J. (1957a). Canad. J. Anim. Sci. 37, 152.

Cunningham, H. M. \& Brisson, G. J. (1957b). F. Anim. Sci. 16, 568.

Cunningham, H. M. \& Loosli, J. K. (1954). F. Dairy Sci. 37, 453.

Dollar, A. M. \& Porter, J. W. G. (1957). Nature, Lond., 179, 1299.

Dukes, H. H. (1955). The Physiology of Domestic Animals, 7th ed., p. 418. Ithaca, NY: Comstock Publishing Company Inc.

Fischer, J. E. \& Sutton, T. S. (1949). Ұ. Dairy Sci. 32, 139.

Flipse, R. J., Huffman, C. F., Webster, H. D. \& Duncan, C. W. (1950). F. Dairy Sci. 33, 548.

Fomon, S. J. (1960). Pediatrics, 26, 51 .

Gullickson, T. W., Fountaine, F. C. \& Fitch, J. B. (1942). Y. Dairy Sci. 25, 1 I 7.

Kastelic, J., Bentley, O. G. \& Phillips, P. H. (1950). F. Dairy Sci. 33, 725.

Lambert, M. R., Jacobson, N. L., Allen, R. S. \& Zaletel, J. H. (1953). F. Dairy Sci. 36, 591.

Lindquist, B. \& Meeuwisse, G. W. (1962). Acta paediat. 51, 674.

Luecke, R. W., Culik, R., Thorp, F. Jr., Blakeslee, L. H. \& Nelson, R. H. (1950). J. Anim. Sci. 9, 420.

Mehring, A. L. Jr., Johnson, D. Jr., Nesbitt, L. L. \& Titus, H. W. (1962). Poult. Sci. $41,249$.

Netke, S. P., Gardner, K. E. \& Kendall, K. A. (r962). J. Dairy Sci. 45, ro5.

Owen, F. G., Jacobson, N. I., Allen, R. S. \& Homeyer, P. G. (1958). F. Dairy Sci. 4r, 662. 
Porter, L. \& Dunn, C. H. (1915). Amer. F. Dis. Child. ro, 77.

Rechcigl, M. Jr., Berger, S., Loosli, J. K. \& Williams, H. H. (1962). J. Nutr. 76, 435.

Rojas, J., Schweigert, B. S. \& Rupel, I. W. (1948). J. Dairy Sci. 31, 81.

Sheehy, E. J. (1955). Animal Nutrition, p. 296. London: Macmillan and Co. Ltd.

Walker, D. M. (1959). F. agric. Sci. 53, 374.

Walker, D. M. \& Faichney, G. J. (1964a). Brit. . Nutr. 18, 187.

Walker, D. M. \& Faichney, G. J. (1964b). Brit. צ. Nutr. 18, 20 r.

Wiese, A. C., Johnson, B. C., Mitchell, H. H. \& Nevens, W. B. (1947). Y. Dairy Sci. 30, 87. 